\title{
TOPICS IN REVIEW
}

\section{Use of opioids to treat chronic, noncancer pain}

The American Medical Association's Council on Scientific Affairs previously addressed barriers to the appropriate management of pain in patients with acute and chronic cancer pain (Report 4, presented at the annual meeting of the AMA, 1995). Authoritative guidelines on these aspects of pain management now exist. ${ }^{1,2}$ However, the use of controlled substances to treat chronic pain in patients who do not have cancer continues to be at the forefront of regulatory, disciplinary, and clinical practice disputes.

A number of critical issues underlie physicians' concerns over the use of opioids in patients with chronic, noncancer pain. These issues include safety and efficacy, the development of tolerance and physical dependence, the potential for drug misuse or addiction, and physicians' fear of regulatory scrutiny and legal sanctions. These issues and the neurobiology of acute and chronic pain are briefly reviewed in this report.

Some physicians continue to undertreat pain. Some of this is influenced by the lack of adequate education and training in pain diagnosis and treatment, which contributes to poor management by physicians of chronic pain. Thus, improvements in education must accompany any initiatives designed to eliminate other barriers.

\section{METHODS}

English-language reports of studies on people were selected from a MEDLINE search of the literature from 1966 to June 1999 using the MeSH headings "analgesics, opioid," "pain," and "chronic disease" but excluding "neoplasm." A total of 257 articles were retrieved. Additional articles were identified by reviewing the references cited in these publications. Further information was obtained from the websites of the American Pain Society (www. ampainsoc.org), the American Academy of Pain Medicine (www.painmed.org), the American Academy of Pain Management (www.aapainmanage.org), the American Society of Addiction Medicine (www.asam.org), the Pain and Policy Studies Group (www.medsch.wisc.edu/ painpolicy), and from recently published textbooks.

\section{NEUROBIOLOGY OF NORMAL AND CHRONIC PAIN}

Pain is an unpleasant sensory and emotional experience associated with actual or potential tissue damage or described in terms of such damage. The perception of pain is influenced by physiological, psychological, and social factors. Thus, the distinction between pain (as the primary sensory experience arising from a noxious stimulus) and

\section{Summary points}

- Peripheral tissue or nerve damage may lead to long-term changes that cause persistent pain in the absence of ongoing stimulation

- Opioids are effective in treating selected patients with chronic pain not related to cancer

- Patients most likely to benefit from opioids are those whose pain has an identifiable cause

- The risk of addiction is increased if a patient has a history of substance abuse but addiction seems to occur infrequently in other patients

- Physicians' fears of regulatory scrutiny play a part in the undertreatment of pain

suffering (the human reaction to the sensory experience) is important. The human reaction (suffering) takes on an added dimension in patients who have chronic, noncancer pain. Some of these patients not only have persistent pain but also have overriding affective components and learned responses that can lead to severe psychosocial disability and a pattern of repeated interaction with the healthcare system.

\section{Nociceptive pain}

Pain is normally evoked by only those stimuli that are sufficiently intense to activate primary afferent A fibers and C-fiber nociceptors. These free nerve endings are located in skin, viscera, muscle, fascia, blood vessels, and joint capsules. There are many varieties of nociceptors, the most important of which are nociceptive afferents and polymodal afferents. Polymodal afferents respond to heat and mechanical stimuli; some also respond to chemical stimuli.

\section{Peripheral sensitization and primary hyperalgesia}

Tissue damage and inflammation cause peripheral sensitization of nociceptors. Sensitized nociceptors have lowered response thresholds. Therefore, they can be activated by a light touch and thermal stimuli that are normally not painful, and during movement. They also exhibit an increased response to stimuli that are normally painful (known as primary hyperalgesia).

\section{Central sensitization, secondary hyperalgesia, and allodynia}

In contrast to A fibers, whose postsynaptic potentials are on the order of milliseconds, C-fiber potentials last up to
Barry D Dickinson Roy D Altman Nancy H Nielsen Michael A Williams, for the Council on Scientific Affairs

Council on Scientific Affairs

American Medical

Association

515 N State Street

Chicago, IL 60610

Correspondence to: Dr Dickinson

barry_dickinson@amaassn.org

Funding: None

Competing interests: None declared

West J Med

2000;172:107-115. A longer version of this article and the names of the staff of the council can be found on the WJM website, www.ewjm.com.

This report was presented at the annual meeting in 1999 of the American Medical Association. The recommendations were adopted as amended. 
20 seconds. ${ }^{3}$ Repetitive C-fiber input changes the excitability of spinal cord neurons. Stimulation at low frequencies causes a progressive prolongation in the response of certain dorsal horn neurons. Persistent stimulation causes central sensitization, which is characterized by an increased excitability of these neurons. ${ }^{4}$ Clinically, it manifests as pain sensitivity beyond the sites of tissue damage or inflammation (secondary hyperalgesia) and the ability of stimuli from low threshold A receptors (which normally mediate light touch and hair movement) to generate sensations of pain or tenderness (mechanical allodynia)., ${ }^{5,6}$ Thus, in the presence of central sensitization, pain can be signaled by large diameter afferents as well as by small diameter afferents. This process is believed to play a major role in neuropathic pain.

\section{Neuropathic pain}

Neuropathic pain results from abnormal operation of the nervous system after injury, usually injury to neural tissue. These types of pathophysiological pain are often chronic and differ qualitatively from acute nociceptive pain. Both peripheral and central changes contribute.

\section{The pain system}

The pain system is subject to ongoing modulation and modulation by injuries. The view that chronic pain is merely an extension of acute nociceptive pain is not valid, particularly in cases of neuropathic pain. With central sensitization, pain can also be signaled by low threshold mechanoreceptors. Ectopic discharges from injured neuronal elements, phenotypic switches, and gene expression also participate in sensory signaling and modulation of central excitability that may ultimately cause persistent pain in the absence of an ongoing stimulus.

\section{MORAL OBLIGATION TO RELIEVE PAIN}

The relief of suffering is universally acknowledged as a cardinal goal of the ethical and compassionate practice of medicine. Pain is a complex phenomenon for both the patient and caregiver, influenced by physiological and psychosocial factors. The challenges of clinical management are heightened by pain since it influences the interpersonal relationship between the patient and the physician. The obligation of physicians to relieve pain is a conditional obligation, in which the ethical principle of beneficence guides a physician's duty to relieve pain (unless a patient of sound mind rejects such treatment). The proffering of treatment and, in some instances the withdrawal of treatment, may relieve suffering and thereby promote good.

The physician also has an ethical obligation to promote the dignity and autonomy of all patients. Physicians must respect the decisions made by competent patients. It is ethically acceptable to administer drugs in whatever dose is necessary to relieve a patient's suffering, even if doing so may cause foreseeable side effects, as long as patients or their proxies are made aware of this possibility. However, physicians should not accede to demands for treatment that are inconsistent with sound medical practice. These concepts apply to the treatment of all types of pain.

\section{TREATMENT OF PATIENTS WITH CHRONIC, NONCANCER PAIN}

Nonopioid drugs are the most commonly used and are often effective treatment for chronic, noncancer pain. Some effective and commonly used nonopioid drugs include acetaminophen, nonsteroidal anti-inflammatory drugs, and adjunctive agents such as antidepressants and antiepileptic drugs. For headache, specific drugs such as selective serotonin agonists and ergot derivatives are appropriate.

In treating mild to moderate pain, increasing the dose of acetaminophen and aspirin or nonsteroidal antiinflammatory drugs beyond a certain point does not provide increased analgesia. Significant side effects are associated with the use of these drugs, especially when large doses are used over prolonged periods. Acetaminophen can cause hepatic injury or failure, and nonsteroidal antiinflammatory drugs increase the risk of gastrointestinal bleeding and ulceration and can cause renal damage. Their use is associated with several thousand hospitalizations annually, with elderly people being at disproportionate risk.

The effects of opioid analgesics are mediated by stereospecific receptors $(\mu, \kappa$, and $\delta){ }^{7}$ Opioid-induced analgesia acts at several sites within the central nervous system and perhaps the periphery as well. Oral, parenteral, transdermal, transmucosal, intrathecal, and epidural administration of opioids can produce analgesia.

Some patients with chronic, noncancer pain respond to nondrug treatment modalities ranging from ice massage to transcutaneous electrical nerve stimulation. Patients, particularly those with substantial disability, which affects their capacity to meet personal, social, or occupational demands, and psychosocial problems, who have not benefited from conventional treatment for pain, are often referred to multidisciplinary pain clinics. These clinics aim to eliminate maladaptive pain behaviors, enable the patient to achieve control of their pain, improve coping through the use of the treatments described above, and to improve psychological functioning, reduce disability, and achieve rehabilitation.

In cases in which less invasive modalities have failed, implantable drug delivery systems (such as intraspinal infusion treatments) are used. In selected patients with severe or unrelenting pain, stimulation of specific central nervous system structures and various neuroablative procedures (such as dorsal rhizotomy, neurolytic nerve block, or intracranial lesioning) have also been used. 


\section{SAFETY AND EFFICACY OF OPIOID THERAPY FOR CHRONIC, NONCANCER PAIN Surveys of patients and physicians}

The main concern about the use of opioids in chronic, noncancer pain is their safety and efficacy. In a questionnaire completed by patients attending pain centers, $83 \%$ of those who were taking opioids reported that the treatment had been at least moderately beneficial. A majority of patients reported no significant adverse effects, and about one-third reported stable dosage requirements and a lack of concern about the possibility of addiction or dependence.

A survey of physicians who were members of the American Pain Society found that many pain specialists believe that long-term opioid treatment is beneficial in selected patients with chronic, noncancer pain; that this treatment is underutilized; and that addiction, tolerance, and physical dependence are generally not significant problems. A national survey also found that a majority of physicians would prescribe long-term opioid treatment for a selected subset of patients with chronic, noncancer pain. Physicians' specialties and geographical location influence their willingness to prescribe opioids, their concern about side effects, and their belief that symptomatic relief alone is sufficient cause to continue the use of opioids.

\section{Clinical surveys and case series}

Several clinical surveys, uncontrolled retrospective studies, and case series on opioid use in patients with this type of pain have been published. Reports encompassing more than 1000 patients have described favorable outcomes in selected samples of patients. ${ }^{8-14}$ Three reports account for about $70 \%$ of these patients (table 1). ${ }^{9,12,13}$

Smaller retrospective surveys have involved diverse patient populations with different diagnoses who were treated with various opioid drugs. Most of these studies are limited by having nonrandomized designs, small patient numbers, and insufficient follow up. The evaluation of outcome often relied on self-reported pain reduction, and different outcomes were selected to indicate success. The results of psychological assessments were generally not reported. Only a few of the studies evaluated changes in functional status, which most pain specialists would agree is important in evaluating the efficacy of treatment in these patients. Documented gains in function were uncommon, ${ }^{11}$ although patients who had either not benefited from pain clinic programs or who had enrolled in an inpatient treatment program experienced improved function. ${ }^{10}$ In a recent study, 12 of 19 patients for whom other treatments had failed responded to dosage titration and fixed interval administration of opioids. ${ }^{14}$ Most of these patients had mixed nociceptive and neuropathic sources of pain, and cognition improved in association with analgesic response.

At least $40 \%$ to $50 \%$ of patients with chronic, noncancer pain evaluated in multidisciplinary treatment programs were already taking opioids. ${ }^{15}$ The prescription of opioids for such patients is influenced by the patient's pain

Table 1 Summary of large clinical surveys of opioid treatment in patients with chronic pain not caused by cancer

\begin{tabular}{|c|c|c|c|c|c|c|c|c|}
\hline Study & $\begin{array}{l}\text { Number of } \\
\text { participants }\end{array}$ & Diagnosis & Opioid used & $\begin{array}{l}\text { Equivalent } \\
\text { daily dose }\end{array}$ & $\begin{array}{l}\text { Duration } \\
\text { of trial }\end{array}$ & $\begin{array}{l}\text { Analgesic } \\
\text { efficacy }\end{array}$ & $\begin{array}{l}\text { Adverse } \\
\text { effects }\end{array}$ & Comments \\
\hline Taub $^{9}$ & 313 & Mixed & Mixed & $\begin{array}{l}10-20 \mathrm{mg} \\
\text { methadone }\end{array}$ & Up to 6 years & $\begin{array}{l}\text { Standard not } \\
\text { described; all } \\
\text { patients said } \\
\text { to benefit }\end{array}$ & $\begin{array}{l}\text { Limited toxicity; drug } \\
\text { abuse occurred in } 4 \%\end{array}$ & $\begin{array}{l}\text { Selection criteria not } \\
\text { specified; no mention of } \\
\text { alternative treatments } \\
\text { provided or tried; changes } \\
\text { in functional status not } \\
\text { reported; } 8 \text { of } 13 \\
\text { participants who abused } \\
\text { drug had history of drug } \\
\text { abuse }\end{array}$ \\
\hline Zenz $^{12}$ & 100 & $\begin{array}{l}\text { Mixed neuropathic } \\
\text { pain }(53 \%) ; \text { back } \\
\text { pain }(24 \%) ; \\
\text { osteoarthritis } \\
(11 \%)\end{array}$ & $\begin{array}{l}\text { Morphine; } \\
\text { buprenor- } \\
\text { phine; dihydro- } \\
\text { codeine }\end{array}$ & $\begin{array}{l}\text { Variable dose of } \\
\text { morphine (range } \\
\text { 20-200 mg); } \\
\text { dose titrated; } \\
\text { administration } \\
\text { on fixed } \\
\text { schedule }\end{array}$ & $\begin{array}{l}\text { Up to } 4 \text { years } \\
\text { (mean } 7 \\
\text { months) }\end{array}$ & $\begin{array}{l}\text { Pain reduced } \\
>50 \% \text { in } 51 \% \text {; } \\
\text { partial pain } \\
\text { reduction in } \\
28 \%\end{array}$ & $\begin{array}{l}\text { Constipation (20\%); } \\
\text { edema }(12 \%) \text {; drug } \\
\text { abuse }(9 \%)\end{array}$ & $\begin{array}{l}\text { Other treatments had failed } \\
\text { participants; adjunctive } \\
\text { treatment not provided; no } \\
\text { psychological assessment; } \\
\text { performance status } \\
\text { improved or declined in } \\
\text { conjunction with analgesia } \\
\text { or lack of response; } \\
\text { patients with neuropathic } \\
\text { pain also improved }\end{array}$ \\
\hline Ytterberg $^{13}$ & 290 & Rheumatic pain* & $\begin{array}{l}\text { Codeine; } \\
\text { oxycodone }\end{array}$ & $\begin{array}{l}\text { About } 81 \mathrm{mg} \\
\text { codeine }\end{array}$ & $>3$ years $(35 \%)$ & $\begin{array}{l}\text { Opioids reduced } \\
\text { rheumatic pain } \\
\text { in }>50 \%\end{array}$ & $\begin{array}{l}38 \% \text { reported side } \\
\text { effects including } \\
\text { nausea, dyspepsia, } \\
\text { constipation; } \\
\text { sedation was most } \\
\text { common side effect; } \\
1 \% \text { of participants } \\
\text { abused drug }\end{array}$ & $\begin{array}{l}\text { Retrospective search of } \\
\text { pharmacy database with } \\
\text { follow-up interview; } \\
\text { increases in dose signalled } \\
\text { progression of disease }\end{array}$ \\
\hline
\end{tabular}

*Population was selected from patients at a rheumatology clinic. 
behavior (nonverbal communication of pain, distress, and suffering). ${ }^{16}$ These programs, and most pain treatment specialists, now endorse an approach that utilizes opioids as an adjunct to a comprehensive treatment strategy using behavioral interventions in combination with other modalities to improve a patient's coping and functional status. ${ }^{17,18}$

Patients referred to specialized pain clinics are usually more challenging clinically than other patients with chronic pain. Patients at pain clinics tend to have higher levels of psychological distress, greater functional impairment, more work-related injuries, lower levels of education, more frequent surgery for pain, and more frequent reports of constant pain. ${ }^{19-22}$ Thus, this population is not representative of the general population of patients with chronic pain.

\section{Prospective, randomized trials}

Several randomized trials have evaluated "opioid responsiveness" in patients with chronic, noncancer pain, particularly neuropathic pain. ${ }^{23-27}$ Clinical experience suggests that opioids are most effective in treating nociceptive pain and less effective in neuropathic pain. In studies using single doses of morphine $(5 \mathrm{mg}$ to $20 \mathrm{mg}$ given intravenously), opioids were ineffective in neuropathic or idiopathic pain, ${ }^{24,28}$ although comparatively larger doses of alfentanil relieved mechanical allodynia in patients with neuropathic pain. ${ }^{26}$ Some reports suggest that pain relief in such patients reflects opioid influences on the affective dimension of pain. ${ }^{28,29}$ However, other studies in which doses were titrated upward (equivalent to $20 \mathrm{mg}$ to $70 \mathrm{mg}$ morphine) found clear dose-response, analgesic effects in patients with neuropathic pain. ${ }^{23,25,27}$

Five randomized, controlled trials have investigated the long-term efficacy of opioids in patients with chronic, noncancer pain (table 2)..$^{30-34}$ Most involved patients

Factors that may be useful in determining if a patient is suitable for ongoing opioid

treatment include:

Relevant findings on medical and psychosocial history Patient's response to other therapeutic strategies The type, intensity, and description of pain

Patient's functional capacity, employment history, and level of social support

Presence of psychopathology and level of emotional distress

Level of coping and the perception of pain and beliefs

Ability to comply with treatment plan

Adverse effects of treatment with opioids

Previous pattern of health care utilization 59 with musculoskeletal pain. Results suggest that titration of dose to either adequate analgesia or intolerable side effects is more effective than the use of fixed doses; effects of opioid treatment on disability, emotional distress, quality of life, and psychological or functional improvement are quite variable; and a subgroup of patients with neuropathic pain does benefit from long-term use of opioids but they are either ineffective or intolerable in many patients with neuropathic pain.

Patients with well-defined nociceptive pain are the most responsive to opioids. Patients with neuropathic and central pain are less responsive but a small subgroup is responsive. Those patients whose pain syndrome is psychologically maintained are generally not responsive to opioids and are not appropriate candidates for opioid treatment.

\section{ADVERSE EFFECTS OF OPIOID TREATMENT}

Long-term treatment with opioids has not been associated with organ toxicity in cancer patients or patients on methadone maintenance. ${ }^{1}$ Most side effects are usually predictable extensions of opioid pharmacology and include respiratory depression, drowsiness, dizziness, nausea, constipation, diaphoresis, decreased sexual function, changes in mood, and pruritus. The occurrence of these side effects may limit the dose that can initially be administered to many patients, interfering with the achievement of adequate pain relief. However, tolerance to most side effects, except constipation, usually occurs, allowing upward titration of the dose until a favorable balance is achieved between analgesia and side effects.

A review of a laboratory and field studies and a large number of studies on the effects of opioids on psychomotor and cognitive functioning in a variety of patients concluded that long-term use of opioids normally should not limit driving or other daily activities. ${ }^{35}$ This does not extend to patients who are initiating titration or who are consuming other psychoactive agents, and it would also be obviated if overt impairment is observable. Clinicians must be vigilant in assessing patients for cognitive or psychomotor impairment, resorting to formal neuropsychological testing if warranted. ${ }^{36}$

\section{TOLERANCE AND PHYSICAL DEPENDENCE}

Analgesic tolerance is not a significant clinical problem for most patients during the treatment of cancer pain. ${ }^{2}$ Most patients with chronic, noncancer pain who are treated with opioids find an effective dose that remains stable for long periods. As with patients with cancer, dose escalation usually reflects progression of a painful lesion rather than drug-seeking, tolerance, or addiction. ${ }^{10,12}$

Physical dependence is defined as the emergence of an abstinence syndrome, which occurs in individuals who 
Table 2 Summary of randomized trials of opioids used to treat chronic pain not caused by cancer

\begin{tabular}{|c|c|c|c|c|c|c|c|c|c|}
\hline $\begin{array}{l}\text { Study } \\
\text { (design) }\end{array}$ & $\begin{array}{l}\text { Number of } \\
\text { participants } \\
\text { (mean age) }\end{array}$ & Diagnosis & $\begin{array}{l}\text { Outcome } \\
\text { measures }\end{array}$ & $\begin{array}{l}\text { Drug } \\
\text { treatment }\end{array}$ & $\begin{array}{l}\text { Equivalent } \\
\text { daily dose* }\end{array}$ & $\begin{array}{l}\text { Duration } \\
\text { of trial }\end{array}$ & Efficacy & $\begin{array}{l}\text { Adverse } \\
\text { effects }\end{array}$ & Comments \\
\hline $\begin{array}{c}\text { Jamison }{ }^{33} \\
\text { (open) }\end{array}$ & $\begin{array}{l}36 \text { (mean } \\
\text { age not } \\
\text { available) }\end{array}$ & $\begin{array}{l}\text { Chronic back } \\
\text { pain }\end{array}$ & $\begin{array}{l}\text { Pain; mood; } \\
\text { activity level; } \\
\text { sleep }\end{array}$ & $\begin{array}{l}\text { Naproxen; } \\
\text { fixed-dose } \\
\text { oxycodone; } \\
\text { oxycodone } \\
\text { and morphine } \\
\text { (CS titrated) }\end{array}$ & Not available & 16 weeks & $\begin{array}{l}\text { Participants in both } \\
\text { opioid groups } \\
\text { did better than } \\
\text { naproxen group; } \\
\text { titrated group } \\
\text { had less pain } \\
\text { and emotional } \\
\text { distress; little } \\
\text { effect on activity } \\
\text { and sleep }\end{array}$ & $\begin{array}{l}\text { None detected; } 1 \\
\text { participant } \\
\text { showed signs of } \\
\text { abusing drug }\end{array}$ & $\begin{array}{l}\text { Little difference } \\
\text { between } \\
\text { pre-treatment } \\
\text { and } \\
\text { post-treatment } \\
\text { measures after } \\
\text { withdrawal from } \\
\text { opiate }\end{array}$ \\
\hline $\begin{array}{l}\text { Moulin } 32 \\
\text { (double- } \\
\text { blind } \\
\text { crossover) }\end{array}$ & $\begin{array}{l}46 \text { (40 } \\
\text { years) }\end{array}$ & $\begin{array}{l}\text { Chronic } \\
\text { regional } \\
\text { pain of soft } \\
\text { tissue or } \\
\text { musculo- } \\
\text { skeletal } \\
\text { origin with } \\
\text { lack of } \\
\text { response to } \\
\text { codeine, } \\
\text { NSAIDs, and } \\
\text { tricyclic } \\
\text { antidepres- } \\
\text { sants }\end{array}$ & $\begin{array}{l}\text { Pain intensity, } \\
\text { psycho- } \\
\text { logical } \\
\text { features, } \\
\text { quality of life, } \\
\text { cognition }\end{array}$ & $\begin{array}{l}60 \mathrm{mg} \text { morphine } \\
\text { SR twice daily; } \\
1 \mathrm{mg} \\
\text { benztropine } \\
\text { twice daily }\end{array}$ & $\begin{array}{r}83.5 \mathrm{mg} ; \\
1.7 \mathrm{mg} \\
\end{array}$ & 9 weeks & $\begin{array}{l}\text { Some analgesic } \\
\text { benefit from } \\
\text { morphine, no } \\
\text { psycho- } \\
\text { logical or } \\
\text { functional } \\
\text { improvement }\end{array}$ & & $\begin{array}{l}\text { Patients also } \\
\text { enrolled in multi- } \\
\text { disciplinary pain } \\
\text { treat- } \\
\text { ment program }\end{array}$ \\
\hline
\end{tabular}

VAS = visual analog scale; NSAIDs = nonsteroidal anti-inflammatory drugs; IV = intravenous

*Range of dose given when known.

have been chronically exposed to a particular drug. The abstinence syndrome is triggered by a reduction in or cessation of a dose or by the administration of a drug with antagonist properties. The administration of pure antagonists, mixed agonist-antagonists, or partial agonists can precipitate an abstinence syndrome in someone who is physically dependent on opioids. The physiological changes that underlie physical dependence will not cause problems as long as abrupt abstinence is avoided, and the presence of physical dependence has not precluded the uncomplicated discontinuation of opioids during the management of noncancer pain.

Patients who are physically dependent may experience subtle withdrawal symptoms between doses that manifest as increased pain. ${ }^{20}$ When these patients increase their opioid dose or frequency of use, they may actually be treating opioid withdrawal. ${ }^{37}$ Such phenomena may contribute to a pattern of drug use in which pain becomes 
sustained or maladaptive behaviors manifest themselves. ${ }^{38}$ This can be minimized with the use of long-acting, controlled-release opioid preparations.

\section{ADDICTION OR ABUSE}

The development of addiction results from an interaction between the inherent reinforcing properties of opioid drugs, such as euphoria or diminished perception of negative feelings or punishment, and predisposing psychologi$\mathrm{cal}$, social, and physiological factors that are uncommon in the heterogeneous population of patients with chronic pain. Tolerance or physical dependence should not be considered diagnostic of addiction in such clinical populations because these are expected consequences of opioid use. $^{38}$

The prevalence of addiction among patients with chronic, noncancer pain is unknown. There are no systematic longitudinal surveys of heterogeneous populations with this type of pain. The exposure of patients to an opioid does not necessarily elicit behavior consistent with addiction. ${ }^{39}$ The rates of drug abuse and addiction in patients with chronic, noncancer pain have been estimated at between $3.2 \%$ and $18.9 \% .{ }^{37,41}$ Higher rates of aberrant drug use have been reported in multidisciplinary pain management programs. ${ }^{19,42}$

Alcoholism or other drug addiction is a contraindication to the use of opioids in patients with chronic noncancer pain. Treatment of pain in such patients or in those with a history of drug abuse or addiction should include consultation with or referral to an expert who can provide skilled assessment and monitoring. ${ }^{38}$ Nonetheless, clinicians must always consider the potential for addiction during the treatment of any patient. The experience of pain management programs further encourages caution in the treatment of patients with idiopathic pain, high levels of psychological distress or disability, previous overuse of medical resources, or overuse of prescription or nonprescription drugs.

\section{PSEUDOADDICTION}

Some healthcare providers misinterpret the seeking of pain relief in patients with pain as aberrant behavior (that is, patients seeking drugs for nontherapeutic purposes). This iatrogenic syndrome, known as "pseudoaddiction," manifests as a direct consequence of inadequate pain relief. 43 Patients' demands for analgesics increase and they become intensely focused on finding relief when pain is unrelieved. These behavioral changes are driven by the severity of the pain, and the misinterpretation of these behaviors may lead to a breakdown in trust between the patient and physician. The provision of adequate pain relief leads to a resolution of this behavior.
Recommendations adopted by the AMA on using opioids to treat chronic pain not related to cancer

Further controlled trials should be conducted on the use of opioids in patients with chronic, noncancer pain in an effort to:

Identify best practice with regard to the selection of regimens for drug treatment and other modalities

Identify the characteristics of patients that predict opioid responsiveness

Provide support for the development of guidelines on appropriate precautions, contraindications, and the degree of monitoring required in such patients

\section{Further recommendations:}

The AMA encourages states to create multidisciplinary task forces or pain commissions to study the barriers to pain management in their state and to make and implement recommendations for policy that will create a practice environment conducive to effective pain management. Guidelines introduced by medical boards are preferable to regulation or statutes.

The AMA and relevant specialty societies should promote educational offerings for physicians to facilitate learning about the principles of the diagnosis and treatment of pain.

The AMA will encourage that appropriate education in pain evaluation and management be provided as an integral part of the core curriculum at all medical schools.

These statements were recommended by the Council on Scientific Affairs at the AMA's annual meeting in 1999

\section{PRESCRIPTION POLICIES AND PHYSICIANS' FEARS OF LEGAL SANCTION}

Prescribing by physicians is subject to state laws and regulations, which sometimes are more restrictive than the federal Controlled Substances Act. Prescribing is reviewed by a number of agencies (state justice departments, state medical boards, local law enforcement agencies, and triplicate prescription monitoring programs). State governments have begun to adopt laws that provide immunity from disciplinary action and criminal prosecution for physicians who treat patients with opioids for chronic or "intractable" pain. This is fraught with risks, however, because intractable pain treatment acts have a number of significant limitations such as defining the medical use of opioids as a therapy of last resort; implying that their use be restricted only to those cases in which the cause of the pain cannot be removed; requiring an evaluation of every patient with pain by a specialist in the organ system believed to be the cause of pain; or excluding patients with a history of substance abuse.

The guidelines developed by medical boards also vary considerably in the conditions and qualifications they describe for the use of opioids to treat patients with chronic, 
noncancer pain. ${ }^{44,45}$ In the past decade, states have adopted or changed laws, regulations, or medical board guidelines to create a practice environment that is conducive to assuring access to appropriate pain relief. To promote consistency in state medical policy, the Federation of State Medical Boards recently adopted model guidelines. ${ }^{46} \mathrm{~A}$ compilation of the current guidelines is available from the University of Wisconsin's Pain and Policy Studies Group (see methods).

Regulatory policies can perpetuate the undertreatment of pain either by impeding access to controlled substances or by influencing prescribing behavior. The institution of multiple-copy prescriptions caused a large decline in prescribing, some of which is best explained by a change in the behavior of legitimate prescribers. ${ }^{47,48}$

Some concerns about inappropriate scrutiny seem to be legitimate; results of a nationwide survey of members of boards of medical examiners found that many would potentially recommend investigation of a prescriber based solely on the knowledge that an opioid had been administered for longer than 6 months to a patient with noncancer pain. ${ }^{49}$

\section{GUIDELINES ON THE USE OF OPIOIDS}

Several sets of guidelines or consensus statements have been promoted recently to try to create a practice environment that is conducive to effectively managing pain while protecting the public from the illegal diversion of controlled substances. ${ }^{50-58}$ In a joint consensus statement issued in 1997, the American Academy of Pain Medicine and the American Pain Society noted that opioids are an essential part of pain management and the societal costs of chronic, noncancer pain are substantial. They also acknowledged that chronic pain is often managed inadequately and that accepted principles of practice should be developed. Additionally, the statement said that state legislatures and regulators must recognize the importance of opioids in treating pain and that principles of good medical practice should guide the prescribing of opioids. ${ }^{58}$

Most guidelines on prescribing opioids also acknowledge that good medical practice should guide prescribing (box). Treatments must be individually tailored to patients with chronic pain, and consideration should be given to different treatment modalities. Most guidelines emphasize how best to prescribe long-term opioid treatment and the importance of monitoring to evaluate effectiveness and the patient's functioning. Minimal guidance is provided on which patients should receive opioids or what criteria should be used to select them. Several guidelines suggest that opioid treatment should be contemplated only after adequate trials of other reasonable alternatives. No empirical studies have been conducted to substantiate these guidelines.

\section{CONCLUSIONS}

A subgroup of patients with chronic, noncancer pain can benefit from long-term opioid treatment. Although selection criteria have not been adequately validated, these patients usually have one or more identifiable causes for their pain. Generally, they have not responded adequately to other analgesics or techniques of pain management or they may receive additional benefit from the adjunctive use of opioids. These patients experience a reduction in pain and have either functional improvement or are functionally stable on opioids. Patients in this category exhibit a reduc-

Common elements of guidelines on using opioids to treat chronic pain ${ }^{50-58}$

\section{Evaluation of the patient}

Obtain a pain history and assess the impact of pain on social, occupational, physical, and psychological function

Review previous diagnostic studies, other consultations and opinions, and previous surgical and medical interventions

Review medical, psychiatric, and substance abuse history and assess coexisting diseases or conditions

Conduct a directed physical examination

\section{Treatment plan and objectives}

Establish a working diagnosis and medical indication for treatment with opioids

Outline measurable outcome objectives (for example, pain control, improvement in activities of daily living, functional improvement)

Provide informed consent on the risks and benefits associated with opioids

Discuss the conditions under which opioids will be prescribed and discontinued

\section{Periodic review}

Assess the safety and efficacy of treatment (for example, subjective pain ratings, functional changes, quality of life, side effects of opioids)

Assess for compliance and evidence of misuse

Reassess the nature of the pain complaint to confirm that opioid treatment is still warranted

\section{Consultation}

Referral to a specialist in pain medicine may be warranted depending on the expertise of the practitioner and the complexity of the problem

Referral to an addiction specialist is often indicated for patients with a history of addiction or substance use disorder

Referral to a psychiatrist or psychologist may be indicated in cases of significant psychiatric comorbidity

\section{Documentation}

Specific documentation on the following areas should be maintained:

Evaluation

Diagnoses (including the reason for prescribing opioids if not obvious from the diagnoses)

All prescriptions written

Overall plan to manage pain

Consultations received

Written instructions to the patient, the patient's consent, and agreements with the patient 
tion in functioning or an increase in suffering when opioids are tapered off or discontinued.

The guidelines that exist to encourage the appropriate use of opioids in patients with chronic, noncancer pain are not treatment algorithms but rather general principles of good medical care. Restrictive regulatory policies on the use of opioids and physicians' fears of regulatory scrutiny continue to play a part in the undertreatment of pain. Until additional controlled scientific data are available, physicians' decisions about opioid use will be based on an evolving clinical consensus influenced by "idiosyncratic, philosophical beliefs created by prior education, populations treated, traditions, myths, and cultural norms interacting with regulatory pressures."

\section{References}

1 Agency for Health Care Policy and Research. Acute pain management: operative or medical procedures and trauma. Clinical practice guideline No. 1. Rockville: AHCPR, 1992. (Publication No. 92-0032.)

2 Agency for Health Care Policy and Research. Management of cancer pain. Clinical guideline No. 9. Rockville: AHCPR, 1994. (Publication No. 94-0592.)

3 Thompson SWN, King AE, Woolf CJ. Activity-dependent changes in rat ventral horn neurons in vitro: summation of prolonged afferent evoked postsynaptic depolarizations produce a C-APV sensitive windup. Eur J Neurosci. 1990;2:638-649.

4 Woolf CJ. Windup and central sensitization are not equivalent. Pain 1996;66:105-108.

5 Coderre TJ, Katz J, Vaccarino AL, et al. Contribution of central neuroplasticity to pathological pain: review of clinical and experimental evidence. Pain 1993;52:259-285.

6 Gracely RH, Lynch SA, Bennett GJ. Painful neuropathy: altered central processing maintained dynamically by peripheral input. Pain 1992;51:175-194.

7 Minami M, Satoh M. Molecular biology of the opioid receptors: structures, function and distributions. Neurosci Res 1996;23:121-145.

8 Portenoy RK, Foley KM, Inturrisi CE. The nature of opioid responsiveness and its implications for neuropathic pain: new hypothesis derived from studies of opioid infusions. Pain 1990;43:273-286.

9 Taub A. Opioid analgesics in the treatment of chronic intractable pain of non-neoplastic origin. In: Kitahata LM, Collins D, eds. Narcotic analgesics in anesthesiology. Baltimore: Williams and Wilkins, 1982:199-208

10 France RD, Urban BJ, Keefe FJ. Long-term use of narcotic analgesics in chronic pain. Soc Sci Med 1984;19:1379-1382.

11 Portenoy RK. Opioid therapy in nonmalignant pain. J Pain Symptom Manage 1990;5(suppl):46-62S.

12 Zenz M, Strumpf M, Tryba M. Long-term opioid therapy in patients with chronic nonmalignant pain. J Pain Symptom Manage 1992;7:69-77.

13 Ytterberg SR, Mahowald ML, Woods SR. Codeine and oxycodone use in patients with chronic rheumatic disease pain. Arthritis Rheum 1998; $41: 1603-1612$.

14 Haythornwaite JA, Menefee LA, Quatrano-Piacentini AL, Pappagallo M. Outcome of chronic opioid therapy for non-cancer pain. J Pain Symptom Manage. 1998;15:185-194.

15 Flor H, Fydrich T, Turk DC. Efficacy of multidisciplinary pain treatment centers: a meta-analytic review. Pain 1992;49:221-230.

16 Turk DC, Okifuji A. What factors affect physicians' decisions to prescribe opioids for chronic noncancer pain patients? Clin J Pain 1997;13:330-336.

17 Aronoff GM. Pain centers: treatment for intractable suffering and disability resulting from chronic pain. In: Aronoff GM, ed. Evaluation and treatment of chronic pain. 3rd ed. Baltimore: Williams and Wilkins; 1998:591-602.

18 Turk DC, Okifuji A. Behavioral management of patients with pain. In:
Aronoff GM, ed. Evaluation and treatment of chronic pain. 3rd ed. Baltimore: Williams and Wilkins, 1998;323-336.

19 Finlayson RD, Maruta T, Morse BR. Substance dependence and chronic pain profile of 50 patients treated in an alcohol and drug dependence unit. Pain 1986;26:167-174.

20 Brodner RA, Taub A. Chronic pain exacerbated by long-term narcotic use in patients with nonmalignant disease: clinical syndrome and treatment. Mt Sinai J Med 1978;45:233-237.

21 Pilowsky I, Chapman CR, Bonica JJ. Pain, depression, and illness behavior in a pain clinic population. Pain 1977;4:183-192.

22 Deyo RA, Bass JE, Schoenfeld NE, et al. Prognostic variability among chronic pain patients: implication for study design, interpretation, and reporting. Arch Phys Med Rehabil 1988;69:174-178.

23 McQuay HJ, Jadad AR, Carroll D, et al. Opioid sensitivity of chronic pain: a patient-controlled analgesia method. Anaesthesia 1992; $47: 757-767$

24 Arner S, Meyerson BA. Lack of analgesic effect of opioids on neuropathic and idiopathic forms of pain. Pain 1988;33:11-23.

25 Jadad AR, Carroll D, Glynn CJ, et al. Morphine responsiveness of chronic pain: double-blind randomised crossover study with patient-controlled analgesia. Lancet 1992;339:1367-1371.

26 Max MB, Byas-Smith MG, Gracely RH, et al. Intravenous infusion of the NMDA antagonist, ketamine, in chronic posttraumatic pain with allodynia: a double-blind comparison to alfentanil and placebo. Clin Neuropharmacol 1995;18:360-368.

27 Rowbotham MC, Reisner-Keller LA, Fields HL. Both intravenous lidocaine and morphine reduce the pain of postherpetic neuralgia. Neurology 1991;41:1024-1028.

28 Kupers RC, Konings H, Adriaensen H, et al. Morphine differentially affects the sensory and affective pain ratings in neurogenic and idiopathic forms of pain. Pain 1991;47:5-12.

29 Winkelmuller M, Winkelmuller W. Long-term effects of continuous intrathecal opioid treatment in chronic pain of nonmalignant etiology. $J$ Neurosurg 1996;85:458-467.

30 Dellemijn PL, van Duijn H, Vanneste JL. Prolonged treatment with transdermal fentanyl in neuropathic pain. J Pain Symptom Manage 1998;16:220-229.

31 Kjaersgaard-Andersen P, Nafei A, Skov O, et al. Codeine plus paracetamol versus paracetamol in longer-term treatment of chronic pain due to osteoarthritis of the hip. A randomised, double- blind, multi-centre study. Pain 1990;43:309-318.

32 Moulin DE, Iezzi A, Amireh R, et al. Randomised trial of oral morphine for chronic non-cancer pain. Lancet 1996;347:143-147.

33 Jamison RN, Raymond SA, Slawsby EA, et al. Opioid therapy for chronic noncancer back pain. A randomized propsective study. Spine 1998;23:2591-2600.

34 Arkinstall W, Sandler A, Goughnour B, et al. Efficacy of controlled-release codeine in chronic non-malignant pain: a randomized, placebo-controlled clinical trial. Pain 1995;62:169-178.

35 Zacny JP. A review of the effects of opioids on psychomotor and cognitive functioning in humans. Exp Clin Psychopharmacol 1995;3:432-466

36 Portenoy RK. Opioid therapy for chronic nonmalignant pain: a review of the critical issues. J Pain Symptom Manage 1996;11:203-217.

37 Fishbain DA, Rosomoff HL, Rosomoff, RS. Drug abuse, dependence, and addiction in chronic pain patients. Clin J Pain 1992;8:77-85.

38 Lu HU, Passik SD, Portenoy RK. Management of chronic pain in the patients with substance abuse. In: Aronoff GM, ed. Evaluation and treatment of chronic pain. 3rd ed. Baltimore: Williams and Wilkins, 1998:421-429.

39 Chapman CR, Hill HF. Prolonged morphine self-administration and addiction liability: evaluation of two theories in a bone marrow transplant unit. Cancer 1989;63:1636-1644.

40 Porter J, Jick H. Addiction rare in patients treated with narcotics. N Engl J Med 1980;302:123.

41 Kouyano K, Pither CE, Wessely S. Medication misuse, abuse and dependence in chronic pain patients. J Psychosomatic Res 1997; 43:497-504

42 Chabal C, Erjavec MK, Jacobson L, et al. Prescription opiate abuse in chronic pain patients: clinical criteria, incidence, and predictors. Clin J Pain 1997;13:150-155.

43 Weissman DE, Haddox JD. Opioid pseudoaddiction - an iatrogenic syndrome. Pain 1989;36:363-366.

44 Joranson DE, Gilson AM. State intractable pain policy: current status. APS Bull 1997;7(2):7-9. 
45 Joranson DE. Medical board guidelines for intractable pain treatment. APS Bull 1995;5(3):1-5.

46 Federation of State Medical Boards of the United States. Model guidelines for the use of controlled substances for the treatment of pain. Fed Bull 1998;85:84-89.

47 Weintraub M, Singh S, Byrne L, et al. Consequences of the $1989 \mathrm{New}$ York triplicate benzodiazepine prescription regulation. JAMA 1991;266:2392-2397.

48 Cooper JR, Czechowicz DJ, Petersen RC, et al. Prescription drug diversion control and medical practice. JAMA 1992;268:1306-1310.

49 Joranson DE, Cleeland CS, Weissman DE, et al. Opioids for chronic cancer and noncancer pain: a survey of state medical board examiners. Fed Bull 1992;4:15-49.

50 Graziotti PJ, Goucke CR. The use of oral opioids in patients with chronic non-cancer pain. Management strategies. Med J Aust 1997; 167:30-34.

51 Hagen N, Flynne P, Hays H, et al. Guidelines for managing chronic non-malignant pain: opioids and other agents. Can Fam Physician 1995; $41: 49-53$

52 Long SP. MSV House of Delegates passes opioid guidelines. Va Med Q 1998;125:8-11. (Medical Society of Virginia pain management subcommittee.)
53 Merry AF, Schug SA, Richards EG, et al. Opioids in the treatment of chronic pain of nonmalignant origin. NZ Med J 1991;11:520-521.

54 Sanders SH, Rucker KS, Anderson KO, et al. Clinical practice guidelines for chronic non-malignant pain syndrome patients. $J$ Bac Musculoskeletal Rehab 1995;5:15-120.

55 Reidenberg MM, Portenoy RK. The need for an open mind about the treatment of chronic nonmalignant pain. Clin Pharmacol Ther 1994;55:367-369.

56 American Society of Anesthesiologists Task Force on Pain Management, Chronic Pain Section. Practice guidelines for chronic pain management. Anesthesiology 1997;86:995-1004.

57 AGS Panel on chronic pain in older persons. The management of chronic pain in older persons. J Am Geriatr Soc 1998;46:635-651.

58 Haddox JD, Joranson D, Angarola RT, et al. The use of opioids for the treatment of chronic pain: a consensus statement from the American Academy of Pain Medicine and the American Pain Society. Clin J Pain 1997;13:6-8.

59 Jamison RN. Comprehensive pretreatment and outcome assessment for chronic opioid therapy in nonmalignant pain. J Pain Symptom Manage 1996;11:231-241.

60 Turk DC. Clinician's attitudes about prolonged use of opioids and the issue of patient heterogeneity. J Pain Symptom Manage 1996;11:218-230.

\section{Update on Alzheimer's disease: recent findings and treatments}

The United Nations estimates that the number of people with dementia in developed countries will increase from 13.5 million to 36.7 million between 2000 and 2050 . $^{1}$ Currently, about 4 million individuals with dementia live in the United States. Alzheimer's disease is the most common form of dementia, accounting for $50 \%$ to $70 \%$ of all cases and more than 100,000 deaths annually. ${ }^{2}$

The disease was first described by Alois Alzheimer in 1907 ; it is a progressive dementia characterized neuropathologically by widespread neuronal loss, $\beta$ amyloid deposits in cerebral blood vessels, the development of neuritic plaques and the presence of neurofibrillary tangles. These

\section{Summary points}

- About $50 \%$ to $70 \%$ of all cases of dementia are Alzheimer's disease

- Risk factors for Alzheimer's disease include being older than 60 years, having a family history of dementia, being female, and having lower levels of educational attainment

- The apolipoprotein $E \varepsilon 4$ allele has been identified as a genetic risk factor for Alzheimer's disease

- The drugs tacrine and donepezil have been approved by the US Food and Drug Administration for use in treating Alzheimer's disease

- In the United States, about $40 \%$ of patients with Alzheimer's disease take donepezil, the most commonly prescribed drug for this condition

- Taking estrogen replacement therapy, anti-inflammatory drugs, and antioxidants may lower the risk and delay the onset of Alzheimer's disease deficits particularly affect the association areas of the cerebral cortex, the hippocampus, and the middle and temporal lobes. Decreased concentrations of the neurotransmitter acetylcholine are also a hallmark of Alzheimer's disease and are strongly associated with the severity of the dementia.

These neuropathologic changes result in the primary symptom of the disease: a decline in memory and cognition that leads to marked impairment in daily functioning. Changes in personality may be present as an early symptom of the illness, and behavioral disturbances including agitation, hallucinations, and delusions often occur as the disease progresses. The duration of the illness is approximately 7 to 10 years from the time of diagnosis; in the later stages of the disease, patients require total care. The overall economic and emotional burden of this illness is significant; the annual cost of caring for patients with Alzheimer's disease in the United States is estimated to be $\$ 119$ billion. $^{3}$

Although there has been important progress in describing and understanding Alzheimer's disease, there is no cure, and researchers are still trying to understand its etiology and pathophysiology. Currently, research is focused both on increasing our understanding of the pathophysiology of the illness to develop appropriate treatments and on identifying the risk factors for Alzheimer's disease to intervene in the preclinical stages of the illness. In this article we summarize the diagnostic criteria for Alzheimer's disease, describe the risk factors and current pharmacologic approaches, and discuss treating patients with the disease.
Ruth O'Hara Martin S Mumenthaler Jerome A Yesavage

Department of

Psychiatry and Behavioral Sciences Stanford University Stanford, CA 94305-5550

Correspondence to: Dr O'Hara roh@leland.stanford.edu

Funding: Please see end of article

Competing interests:

None declared

West J Med 2000;

172:115-120 


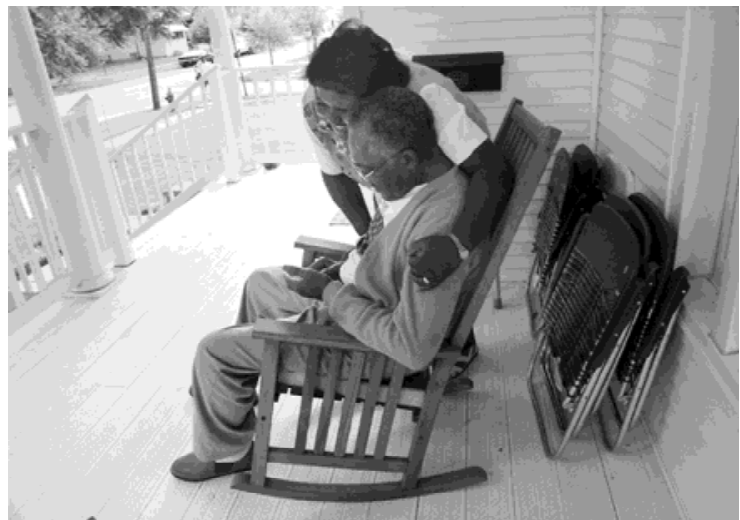

Many patients with Alzheimer's disease need total care

\section{METHODS}

This overview is based on findings from recent epidemiologic and experimental studies as well as randomized clinical trials. In addition to the data and literature available through Stanford's Aging Clinical Research Center, we conducted MEDLINE and PsychLit searches using the terms "Alzheimer's disease" and "dementia", and searched the Cochrane Library database. This review also draws on additional literature reviews and the opinions of leaders in subspecialties of research into Alzheimer's disease.

\section{DIAGNOSTIC CRITERIA}

The standard clinical criteria for the diagnosis of Alzheimer's disease were developed by the National Institute of Neurological and Communicative Disorders and Stroke and the Alzheimer's Disease and Related Disorders Association. ${ }^{4}$ Alzheimer's disease is classified as into one of three diagnostic categories: definite Alzheimer's disease, probable Alzheimer's disease, and possible Alzheimer's disease. The diagnosis of definite Alzheimer's disease requires histopathologic confirmation of clinical features by postmortem examination. Diagnoses made from the findings of the postmortem examination correspond to antemortem diagnoses about $90 \%$ of the time. ${ }^{5}$

In general, the criteria for the clinical diagnosis of probable Alzheimer's disease include onset between the ages of 40 and 90; no disturbance of consciousness; dementia established by clinical examination and a standardized assessment of mental status, which is supplemented by neuropsychologic tests; deficits in two or more areas of cognition (one of which is memory) that are characterized by gradual onset and progression; absence of systemic disorders or other brain diseases that could account for the progressive deficits in memory and cognition; and the deficits do not occur exclusively during an episode of delirium.

The clinical diagnosis of possible Alzheimer's disease is made using the same criteria as probable Alzheimer's dis- ease except that only a single, progressive, severe cognitive deficit is identified and other identifiable causes are absent. Because this deficit is often memory loss alone there is sometimes an overlap between this syndrome and what is referred to as "mild cognitive impairment." However, mild cognitive impairment typically involves milder memory loss than would be observed in dementia and also requires the absence of functional impairment. ${ }^{6}$

\section{RISK FACTORS}

Many investigators emphasize that intervening during both the preclinical and the early stage of Alzheimer's disease may prolong the functioning of patients and extend the length of time before they are placed in institutional care. Identifying candidates in the preclinical stages of the illness requires knowledge of the risk factors for Alzheimer's disease, and a large amount of research aims to identify these factors.

\section{Age}

Both the prevalence and incidence of Alzheimer's disease increase with advancing age, seeming to double about every 5 years after the age of $60 .^{2,} 7$ The strong association between age and Alzheimer's disease has led investigators to suggest that biologic processes associated with aging may play a part in the development of the disease but that genetic, psychosocial, and environmental risk factors alter the age-specific rates of the illness. ${ }^{8}$

\section{Genetic vulnerability}

In the past 10 years there has been an important increase in our understanding of the genetic etiology of Alzheimer's disease. Point mutations in genes on chromosomes 1,14 , and 21 are expressed as autosomal traits linked to the development of early-onset Alzheimer's disease in specific families; however, patients with these mutations account for less than $5 \%$ of all patients with Alzheimer's disease. $^{5}$

Several susceptibility genes for Alzheimer's disease have been identified. In particular, the apolipoprotein $\mathrm{E} \varepsilon 4$ allele is a genetic risk factor for the development of Alzheimer's disease. ${ }^{9}$ Apolipoprotein $\mathrm{E}$ is a protein that is thought to be active in the transport of plasma cholesterol and the repair of neurons. Apolipoprotein E is encoded by a gene on chromosome 19, and there are three allelic variants $(\varepsilon 2, \varepsilon 3, \varepsilon 4)$, yielding six possible genotypes. The presence of the $\varepsilon 4$ allele is associated with a dosedependent increased risk of Alzheimer's disease. Individuals with one $\varepsilon 4$ allele have twice the risk of developing the disease as people without the allele, and individuals who are homozygous for the allele are 10 times more likely to develop the disease. ${ }^{10}$ However, studies have not found a strong association between the allele and progression of 
the disease, although there may be an association between the presence of the $\varepsilon 4$ allele and the behavioral symptoms of Alzheimer's disease. ${ }^{11}$

Although it has been suggested that apolipoprotein $\mathrm{E}$ affects the deposition of amyloid, the development of neurofibrillary tangles, and cholinergic function, the exact pathophysiologic link between the $\varepsilon 4$ allele and Alzheimer's disease remains unclear. Individuals without any of these susceptibility genes may develop the disease, but those who have genetic risk factors may never develop it. $^{7,12}$ The current recommendations of the National Institute of Aging and the Alzheimer's Disease and Related Disorders Association are that genotyping for the allele should not be used to predict the risk of developing Alzheimer's disease in people without symptoms and should not be used as the sole diagnostic test for the disease. ${ }^{13}$

\section{Family history of dementia}

Having a family history of dementia is a risk factor for Alzheimer's disease; this risk extends beyond those family members who have genetic markers for susceptibility. The risk seems to increase between two- and four-fold among people who have a first-degree relative with the disease. ${ }^{5}$

\section{Other possible risk factors}

Prevalence studies have identified higher rates of Alzheimer's disease in women. ${ }^{5}$ However, these studies have often included only a small number of men with the disease, thus rendering the estimate of prevalence unstable. Higher levels of educational attainment are associated with a delay in the onset of the disease and lower levels with an increased risk. ${ }^{7}$ Investigators have suggested that education may increase synaptic density and thus minimize or delay the effects of neuronal loss associated with the disease. ${ }^{14}$ However, having less education may be a proxy for other factors such as poor nutrition and test bias. The observation of an association between arteriosclerosis, the $\varepsilon 4$ allele, and risk of Alzheimer's disease has led to consideration of vascular risk factors in the etiology of the illness. ${ }^{15}$ Other suggested risk factors include traumatic head injury, depression, low levels of occupational attainment, and engaging in fewer social activities. ${ }^{16,}{ }^{17}$ Interactions among these individual risk factors can significantly affect the degree of risk. For example, the age of onset of Alzheimer's disease in women who have both the $\varepsilon 4$ allele and a family history of dementia has been found to be significantly lower than that in women who have only one of these risk factors. Although the identification of risk factors can suggest that someone is at risk of developing Alzheimer's disease, some individuals who have a variety of risk factors may never develop the illness. ${ }^{18}$

\section{CURRENT PHARMACOLOGIC APPROACHES}

Pharmacologic treatments for Alzheimer's disease are generally recommended only for those patients who already have been diagnosed with mild to moderate disease. However, several studies are investigating pharmacologic treatments in people who do not yet have the disease but are at risk of developing it. For example, the National Institute of Aging is currently funding an investigation into the effectiveness of donepezil in individuals with mild cognitive impairment.

Neurobiologic features, such as the accumulation of amyloid and the reduction in acetylcholine, and possible impairments in immune and inflammatory mechanisms have informed the development of current pharmacologic approaches. Clinicians must rule out any other potentially treatable causes of the symptoms of dementia such as thyroid disease, alcoholism, or drug toxicity before their patients begin drug treatment. ${ }^{16}$

\section{Acetylcholinesterase inhibitors}

The best developed approach to treatment aims at correcting the deficit of acetylcholine which is associated with Alzheimer's disease. Acetylcholinesterase inhibitors include first-generation compounds such as physostigmine and tacrine and second-generation compounds such as donepezil and metrifonate and rivastigmine. These compounds increase the concentration of acetylcholine and the duration of its action in synapses by inhibiting the acetylcholinesterase enzyme (which metabolizes acetylcholine). Acetylcholinesterase inhibitors are currently the most successful drugs used to enhance the transmission of acetylcholine, and they may be more beneficial than direct activation of cholinergic receptors.

In 1993, tacrine became the first cholinesterase inhibitor to receive approval from the Food and Drug Administration for use in patients with Alzheimer's disease; treatment with tacrine, however, resulted in only modest improvements in cognition. ${ }^{19}$ Tacrine has a lower bioavailability than second-generation cholinesterase inhibitors such as rivastigmine and donepezil, and it has a worse side-effect profile which includes hepatotoxicity. ${ }^{20,21}$

Donepezil is a highly selective, noncompetitive, reversible, second-generation acetylcholinesterase inhibitor that received approval from the Food and Drug Administration in $1996 .^{22}$ In phase 2 and phase 3 clinical trials, treatment with donepezil significantly improved cognition, scores on the global assessment of change, and reduced the severity of the disease when compared with placebo. ${ }^{23-25}$ Donepezil has a better side-effect profile, is not hepatotoxic, and more patients are able to tolerate donepezil at therapeutic doses than can tolerate tacrine. ${ }^{19}$ Other second-generation cholinesterase inhibitors are either already on the market (for example, rivastigmine in the United States and Europe) or have been submitted for approval in the United States (metrifonate). Initial trials have found that the magnitude of improvement in patients treated with rivastigmine matches or exceeds that of 
other compounds. ${ }^{26}$ However, rivastigmine seems to require a longer period of titration than donepezil before a therapeutic dose is reached. ${ }^{27}$

\section{Estrogen}

Epidemiologic studies have suggested that in women estrogen replacement therapy may significantly delay the onset of Alzheimer's disease and lower the risk of developing it. ${ }^{28,29}$ Several small randomized clinical trials found that treatment with estrogen improved cognition in patients with the disease. ${ }^{30,31}$ Additionally, a clinical trial of tacrine found that women who also took estrogen exhibited significantly better cognitive performance than women taking only tacrine or placebo. ${ }^{32}$

The ability of estrogen to act both as an antioxidant and an anti-inflammatory agent may explain its association with a reduction in risk. ${ }^{33-35}$ Estrogen also increases acetylcholine concentrations and may promote the growth and survival of neurons in the regions of the brain that are most sensitive to degeneration in Alzheimer's disease. ${ }^{36}$ Additionally, it has been suggested that estrogen reduces neuronal injury by reducing the metabolism of $\beta$ amyloid from its precursor protein. ${ }^{37}$ However, not all studies have found that estrogen reduces the risk of Alzheimer's disease. ${ }^{29}$ Because the decision to take estrogen replacement therapy may be affeted by differences in occupational, educational or socioeconomic status, the epidemiological evidence must be balanced by data from randomized, controlled clinical trials. Additionally, further studies assessing the safety of estrogen replacement therapy in treating Alzheimer's disease are required.

\section{Anti-inflammatory drugs}

The inverse relation between rheumatoid arthritis and Alzheimer's disease has led to the hypothesis that antiinflammatory agents reduce the risk of developing the disease. Anti-inflammatory drugs may affect the inflammatory processes associated with the development of neuritic plaques. An association between the use of nonsteroidal anti-inflammatory drugs and a decreased risk of Alzheimer's disease has been identified in the literature but there have been few randomized clinical trials. ${ }^{38}$ The Alzheimer's disease cooperative study is looking at the possible effects of steroids and is conducting a multicenter, randomized, placebo-controlled trial of treatment with prednisone in patients with Alzheimer's disease. However, some investigators have suggested that prednisone can have adverse effects on memory, ${ }^{39}$ and adverse gastrointestinal effects have been observed in studies of antiinflammatory drugs..$^{40}$ Several clinical trials of the potential role of the nonsteroidal anti-inflammatory cyclooxygenase-2 inhibitors both in patients with Alzheimer's disease and people at risk for the disease are under way. These inhibitors are less toxic than other nonsteroidal anti- inflammatory drugs, which is important in the treatment of elderly adults.

\section{Antioxidants}

The products of oxidative metabolism, such as free radicals, may be neurotoxic. ${ }^{41} \beta$ amyloid neurotoxicity may be mediated through the formation of free radicals. Agents that protect against this oxidative damage, such as vitamin E and Ginkgo biloba extract, are thought to reduce neuronal damage and potentially slow the onset and progression of Alzheimer's disease. Initially, clinical trials found that treatment with Ginkgo biloba was associated with significant but modest improvements in cognition in patients with Alzheimer's disease. ${ }^{42,43}$ The ability to generalize from these findings is limited because the diagnostic criteria and the outcome measures used were variable. ${ }^{44} \mathrm{~A}$ controlled trial found that the antioxidants selegiline and vitamin $\mathrm{E}$, alone or in combination, delayed progression to a mixed endpoint defined as severe functional decline, nursing home placement, or death. ${ }^{45,46}$

\section{TREATING PATIENTS WITH ALZHEIMER'S DISEASE}

A consensus statement on the diagnosis and treatment of dementia, produced by the American Association for Geriatric Psychiatry and the American Geriatrics Society, emphasized that cholinesterase inhibitors are the mainstay of pharmacologic treatment of patients with Alzheimer's disease. $^{47}$ In the Unites States, about $40 \%$ of patients with the disease take donepezil. ${ }^{22}$

Donepezil is generally prescribed to patients with mild to moderate dementia at a starting dose of $5 \mathrm{mg}$ per day. Many clinicians increase the dose to $10 \mathrm{mg}$ per day after 10 weeks. Side effects seem to be better tolerated if the dose is increased over this time instead of starting patients on a $10 \mathrm{mg}$ dose. Since donepezil has only recently become more widely used in clinical practice data on longterm benefits are limited, and it is unclear how long patients should remain on the drug. Similarly, there are limited data available to indicate which patients respond best to cholinesterase inhibitors, although preliminary finding suggest that patients with the apolipoprotein E $\varepsilon 4$ allele do not respond as well to these agents as patients without this allele. ${ }^{48}$ Longitudinal follow up of patients treated with cholinesterase inhibitors will likely yield important information regarding how long treatment should be provided for and for whom it should be provided.

Although estrogen, anti-inflammatory drugs, and antioxidants seem to offer promise in treating and preventing Alzheimer's disease, their use is limited by the fact that their efficacy has yet to be established. Additionally, they are associated with a broad range of adverse side effects and physicians may be unwilling to expose their patients to these side effects without sufficient evidence of their effi- 
cacy. When information is available from the larger trials that are currently in progress their benefits will be able to be assessed more fully.

The consensus statement on the diagnosis and treatment of dementia suggested that antipsychotic agents could be helpful in controlling the behavioral problems that may occur, such as agitation and aggression. The statement cautions that such agents can have adverse side effects ranging from parkinsonian symptoms to delirium and sedation. Recent studies with atypical antipsychotics suggest that low doses of drugs such as risperidone may be effective in treating agitation and psychosis in these patients. ${ }^{49,50}$

Several investigators have emphasized the importance of nonpharmacologic approaches to treating both the cognitive and behavioral problems associated with Alzheimer's disease, ${ }^{16,51}$ and the necessity of providing adequate information to both the patient and the caregiver on community resources and social services. ${ }^{52}$

\section{NEW DEVELOPMENTS AND DIRECTIONS FOR RESEARCH}

Cholinesterase inhibitors continue to be developed and refined. Other pharmacologic developments are based on different approaches. Muscarinic agonists are being developed to enhance the effect of acetylcholine on nerve cell receptors. The depletions of other neurotransmitters, including serotonin and norepinephrine, that occur in Alzheimer's disease are also being considered as possible targets for treatment.

Reducing $\beta$ amyloid is an approach also being targeted as a pharmacologic intervention. One strategy aims to develop compounds that will decrease deposits of $\beta$ amyloid by inhibiting the enzymes that form amyloid but such treatments are still in the initial phases of development and safety testing. ${ }^{53}$ Another preliminary study observed that beta-amyloid deposits were reduced in laboratory mice after treatment with a vaccine that combined amyloid with substances that stimulate the immune system. ${ }^{54}$

In addition to the assessment of new pharmacologic treatments for Alzheimer's disease, there is a developing emphasis on investigating which patients derive the most benefit from which treatments.

Our understanding of the genetic etiology of Alzheimer's disease continues to increase. Studies are in progress to confirm the preliminary observations of associations between Alzheimer's disease and polymorphisms in several genes, some of which may interact with apolipoprotein $\mathrm{E}$ to alter the risk of Alzheimer's disease (for example, the $\alpha_{2}$-macroglobulin gene). In addition to enhancing our knowledge of the genetic etiology of the disease, future research will likely focus on increasing our understanding of the interactions between genetic vulnerabilities and psychosocial risk factors for the disease.
Funding: We would like to thank the Brookdale Foundation; the Institute for Research on Women and Gender; the Stanford Aging Clinical Research Center; the VA Sierra-Pacific Mental Illness Research, Education, and Clinical Center; and the Medical Research Service of the VA Palo Alto Health Care System for their support of this work.

References

1 United Nations. World population prospects: the 1996 revision. Washington, DC: Population division of the Department of Economic and Social Affairs of the United Nations Secretariat, 1998.

2 Evans DA, Funkenstein HH, Albert MS, et al. Prevalence of Alzheimer's disease in a community population of older persons. JAMA 1989;262:2551-2556.

3 Katzman R, Fox P. The world-wide impact of dementia. Projections of prevalence and costs. In: Mayeaux R, Christen Y, eds. Epidemiology of Alzheimer's disease: from gene to prevention. New York: Springer-Verlag, 1999:1-17.

4 McKhann G, Drachman D, Folstein M, et al. Clinical diagnosis of Alzheimer's disease: a report of the NINCDS-ADRDA work-group under the auspices of the Department of Health and Human Services Task Force on Alzheimer's disease. Neurology 1984;34:939-944.

5 Mayeaux R. Predicting who will develop Alzheimer's disease. In: Mayeaux R, Christen Y, eds. Epidemiology of Alzheimer's disease: from gene to prevention. New York: Springer-Verlag, 1999:19-31.

6 Peterson RC, Smith GE, Waring SC, et al. Mild cognitive impairment: clinical characterization and outcome. Arch Neurol 1999;56:303-308.

7 Cummings JL, Vinters H, Cole G, et al. Alzheimer's disease: etiologies, pathophysiology, cognitive reserve and treatment opportunities. Neurology 1998;51(suppl 1):2-17S.

8 Lendon C, Ashall F, Goate, AM. Exploring the etiology of Alzheimer disease using molecular genetics. JAMA 1997;277:825-831.

9 Strittmatter WJ, Roses AD. Apolipoprotein E and Alzheimer's disease. Annu Rev Neurosci 1996;19:53-57.

10 Slooter AJC, Cruts M, Kalmijn S, et al. Apolipoprotein E and dementia. Risk estimates from a population-based incidence study: the Rotterdam study. Arch Neurol 1998;55:964-968.

11 Murphy GM, Taylor J, Tinklenberg JR, et al. The apolipoprotein E epsilon 4 allele is associated with increased behavioral disturbance in Alzheimer's disease [letter]. Am J Geriatr Psychiatry 1997;5:88-89.

12 O'Hara R, Yesavage JA, Kraemer HC, et al. The APOE $\epsilon^{4}$ allele is associated with decline on delayed recall performance in community-dwelling older adults. J Am Geriatr Soc 1998;46:1493-1498.

13 Relkin NR, Younga JK, Tsai J, et al. The National Institute on Aging/Alzheimer's Association recommendations on the application of apolipoprotein E genotyping to Alzheimer's disease. Ann N Y Acad Sci 1996;802:149-171.

14 Katzman R. Education and the prevalence of dementia and Alzheimer's disease. Neurology 1993;43:13-20.

15 Haan M, Shemanski L, Jagust WJ, et al. The role of APOE e4 in modulating effects of other risk factors for cognitive decline in elderly persons. JAMA 1999; 282:40-46.

16 Small GW. Treatment of Alzheimer's disease: current approaches and promising developments. Am J Med 1998;104(suppl):32-38S.

17 Bassuk SS, Glass TA, Berkman LF. Social disengagement and incident cognitive decline in community-dwelling elderly persons. Ann Intern Med 1999;131:165-73.

18 Duara R, Lopez-Alberola R, Barker WW, et al. Age at onset of Alzheimer's disease (AD): interaction of gender, family history, and apolipoprotein E genotype. Neurology 1995;45(suppl 4):A470.

19 Sirvio J. Strategies that support declining cholinergic neurotransmission in Alzheimer's disease patients. Gerontology 1999;45:3-14.

20 Nordberg A, Svensson AL. Cholinesterase inhibitors in the treatment of Alzheimer's disease: a comparison of tolerability and pharmacology [published correction appears in Drug Saf 1999 Feb;20:146]. Drug Saf 1998;19:465-480.

21 Qizilbash N, Birks J, Lopez Arrieta J, et al. Tacrine for Alzheimer's disease. Cochrane Library. Issue 4. Oxford: Update Software, 1999.

22 Schneider LS. New therapeutic approaches to cognitive impairment. $J$ Clin Psychiatry 1998;59:8-13.

23 Burns A, Rossor M, Hecker J, et al. The effects of donepezil in Alzheimer's disease-results from a multinational trial. Dement Geriatr Cogn Disord 1999;10:237-244.

24 Rogers SL, Doody RS, Mohs RC, et al. Donepezil improves cognition 
and global function in Alzheimer disease: a 15-week, double-blind, placebo-controlled study. Arch Intern Med 1998;158:1021-1031.

25 Birks JS, Melzer D. Donepezil for mild and moderate Alzheimer's disease. Cochrane Library. Issue 4. Oxford: Update Software, 1999

26 Birks J, Iakovidou V, Tsolaki M. Rivastigmine for Alzheimer's disease. Cochrane Library. Issue 4. Oxford: Update Software, 1999.

27 Krall WJ, Sramek JJ, Cutler NR. Cholinesterase inhibitors: a therapeutic strategy for Alzheimer disease. Ann Pharmacother 1999;33:441-450.

28 Kawas C, Resnick S, Morrison A, et al. A prospective study of estrogen replacement therapy and the risk of developing Alzheimer's disease: the Baltimore longitudinal study of aging. Neurology 1997;48:1517-1521.

29 Henderson VW. The epidemiology of Alzheimer's disease: the role of estrogen in reducing risk. In: Mayeaux R, Christen Y, eds. Epidemiology of Alzheimer's disease: from gene to prevention. New York: Springer-Verlag; 1999:49-63

30 Honjo H, Ogino Y, Tanaka K, et al. An effect of conjugated estrogen to cognitive impairment in women with senile dementia-Alzheimer's type: a placebo-controlled, double-blind study. J Jpn Menopause Soc 1993; 1:167-171.

31 Asthana S, Craft S, Baker LD, et al. Cognitive and neuroendocrine response to transdermal estrogen in postmenopausal women with Alzheimer's disease: results of a placebo-controlled, double-blind pilot study. Psychoneuroendocrinology 1999;24:657-677.

32 Schneider LS, Farlow MR, Henderson VW, et al. Effects of estrogen replacement therapy on response to tacrine in patients with Alzheimer's disease. Neurology 1996;46:1580-1584.

33 Behl C, Skutella T, Lezoualch F, et al. Neuroprotection against oxidative stress by estrogens: structure-activity relationship. $\mathrm{Mol}$ Pharmacol 1997;51:535-541.

34 Nathan L, Chaubhuri G. Antioxidant and prooxidant actions of estrogens: potential physiological and clinical implications. Semin Reprod Endocrinol 1998;16:309-314.

35 Yaffe K, Sawaya G, Lieberburg I, et al. Estrogen therapy in postmenopausal women: effects on cognitive function and dementia. JAMA 1998;279:688-695.

36 Wickelgren I. Estrogen stakes claim to cognition. Science 1997;276:675-678.

37 Jaffe AB, Toran-Allerand CD, Greengard P, et al. Estrogen regulates metabolism of Alzheimer amyloid beta precursor protein. J Biol Chem 1994;269:13065-13068.

38 Kawas CH. Inflammation, anti-inflammatory drugs and Alzheimer's disease. In: Mayeaux R, Christen Y, eds. Epidemiology of Alzheimer's disease: from gene to prevention. New York: Springer-Verlag; 1999:65-72.

39 Aisen PS, Marin D, Altstiel L, et al. A pilot study of prednisone in Alzheimer's disease. Dementia 1996;7:201-206.
40 Rogers J, Kirby LC, Hempelman SR, et al. Clinical trial of indomethacin in Alzheimer's disease. Neurology 1993;43:1609-1611.

41 Sayre LM, Zagorski MG, Surewicz WK, et al. Mechanisms of neurotoxicity associated with amyloid beta deposition and the role of free radicals in the pathogenesis of Alzheimer's disease: a critical appraisal. Chem Res Toxicol 1997;10:518-526.

42 Le Bars PL, Katz MM, Berman N, et al. A placebo-controlled, double-blind, randomized trial of an extract of Ginkgo biloba for dementia. JAMA 1997;278:1327-1332.

43 Kanowski S, Hermann WM, Stephan K, et al. Proof of efficacy of the ginkgo biloba special extract EGb 761 in outpatients suffering from mild to moderate primary degenerative dementia of the Alzheimer type or multi-infarct dementia. Pharmacopsychiatry 1996;29:47-56.

44 Oken BS, Storzbach DM, Kaye JA. The efficacy of Ginkgo biloba on cognitive function in Alzheimer disease. Arch Neurol 1998;55:1409-1415.

45 Sano M, Ernesto C, Thomas RG, et al. A controlled trial of selegiline, alpha-tocopherol, or both as treatment for Alzheimer's disease. N Engl J Med 1997;336:1216-1222.

46 Birks J, Flicker L. Selegiline for Alzheimer's disease. Cochrane Library. Issue 4. Oxford: Update Software, 1999.

47 Consensus on diagnosis and treatment of dementia: summary of recommendations. American Geriatric Society Symposia May 1998:13-14.

48 Poirier J. Apolipoprotein E4, cholinergic integrity and the pharmacogenetics of Alzheimer's disease. J Psychiatry Neurosci 1999;24:147-153

49 De Deyn PP, Rabheru K, Rasmussen A, et al. A randomized trial of risperidone, placebo, and haloperidol for behavioral symptoms of dementia. Neurology 1999;53:946-955.

50 Katz IR, Jeste DV, Mintzer JE, et al. Comparison of risperidone and placebo for psychosis and behavioral disturbances associated with dementia: a randomized, double-blind trial. J Clin Psychiatry 1999;60:107-115.

51 Teri L, Logsdon RG, Uomoto J, et al. Behavioral treatment of depression in dementia patients: a controlled clinical trial. J Gerontol B Psychol Sci Soc Sci 1997;52:P159-P166.

52 Thompson C, Thompson G. Support for carers of people with Alzheimer's type dementia. Cochrane Library. Issue 4. Oxford: Update Software, 1999

53 Toide K, Iwamoto Y, Fujiwara T, et al. JTP-4819: a novel prolyl endopeptidase inhibitor with potential as a cognitive enhancer. $J$ Pharmacol Exp Ther 1995;274:1370-1378.

54 Schenk D, Barbour R, Dunn W, et al. Immunization with amyloid-beta attenuates Alzheimer-disease-like pathology in the PDAPP mouse. Nature 1999;400:173-177.

\section{A Book to Make You Think}

\section{In the blood: sickle cell anemia and the politics of race, Melbourne Tapper, University of Pennsylvania Press, 160 pp, ISBN 0812234715}

"Race" is a concept that has occupied a prominent place in the North American culture for centuries. Despite the vagueness of the concept, the use of race in health research has a long and sometimes disturbing history. Thousands of publications exist on black-white differences in behavior and disease patterns. Most anthropologists have rejected the traditional western notion of race-as bounded, identifiable biologic groups-both as a research tool and as valid representation of biologic diversity. Nevertheless, the racialization of disease continues to be pervasive, often providing researchers with simple and convenient explanations for complex socioeconomic determinants of ill health.

Since its identification in 1910, sickle cell anemia has been characterized as a "black" disease, despite its occurrence in people of Greek, Italian, Indian, and Latin American ancestry. In the blood examines why this is. Tapper's critical analysis of anthropologic, medical, genetic, and political discourses on sickle cell anemia during the past century leads him to conclude that the scientific inquiry of the disorder was driven by such notions as racial difference and genetic purity and superiority. He argues convincingly that, by using the ostensibly value-free science of genetics and laboratory medicine, these eugenic ideas were legitimized and normalized.

Sickle cell anemia has been used to question the racial identity of white patients afflicted by the disease; to support prevalent social concerns about the interbreeding of races and, more generally, the dangers inherent in "negro blood"; and even to uphold the notion that modern humans evolved from multiple origins. Tapper comprehensively examines these and other issues. He provides only sketchy details, however, on how the disorder was used to further the cause of the civil rights movement in the United States and omits discussion about the disastrous misinformation provided about the disease during the 1960s and 1970s by the Black Panthers.

Sickle cell anemia remains a controversial disorder even today. Whereas universal newborn screening for the disease has been implemented in most US states, many centers use targeted screening. High-risk groups continue to be identified by racial and ethnic traits. The value of universal screening is supported by the results of California's newborn hemoglobinopathy screening program, which identified 7,000 nonblack carriers of the sickle cell trait or disease among 2 million infants screened.

In the blood has something to convey beyond what it says about sickle cell anemia. Tapper bases his work on the notion, espoused by 19th century French critical thinkers such as Foucault and Delaporte, that disease does not exist outside of discourse and practice. It provides a fine example of an analytic framework that could be used to critically review current research linking conditions such as hypertension, low birth weight, and the acquired immunodeficiency syndrome (AIDS) to race. I found this a stimulating read — once the turgid introductory chapter was negotiated — and a valuable contribution to the literature on the social construction of race and disease.

Haroon Saloojee

University of the Witwatersrand, Johannesburg, South Africa

A version of this article first appeared in the $B M J$ 